EXISTENCE AND UNIQUENESS OF MONOTONE POSITIVE SOLUTIONS

\title{
FOR A THIRD-ORDER THREE-POINT BOUNDARY VALUE PROBLEM
}

\author{
Li ZhaO, WEIXUAN WANG AND CHENGBo ZHAI
}

Abstract. In this paper, we study the existence and uniqueness of monotone positive solutions for a class of nonlinear third-order three-point boundary value problem. The main tool is a fixed point theorem of generalized concave operators in ordered Banach spaces. An example is given to illustrate the main result.

Mathematics subject classification (2010): 34B18, 34B15.

Keywords and phrases: Monotone positive solution, third-order differential equation, three-point boundary value problem, fixed point theorem of generalized concave operators.

\section{REFERENCES}

[1] D. R. Anderson, Green's function for a third-order generalized right focal problem, Journal of Mathematical Analysis and Applications 288 (1) (2003), 1-14.

[2] D. R. ANDERSON, J. M. DAVIS, Multiple solutions and eigenvalues for third-order right focal boundary value problems, Journal of Mathematical Analysis and Applications 267 (2002), 135-157.

[3] X. FENG, H. FENG, D. BAI, Eigenvalue for a singular third-order three-point boundary value problem, Applied Mathematics and Computation 219 (2013), 9783-9790.

[4] Y. FEnG, S. LIU, Solvability of a third-order two-point boundray value problem, Applied Mathematics Letters 18 (2005), 1034-1040.

[5] J. R. Graef, B. YAng, Positive solutions of a nonlinear third order eigenvalue problem, Dynamic Systems and Applications 15 (2006), 97-110.

[6] M. Gregus, Third Order Linear Differential Equations, Mathematics Applications Reidel, Dordrecht, 1987.

[7] A. Guezane-Lakoud, S. Kelaiaia, Solvability of a three-point nonlinear boundary-value problem, Electronic Journal of Differential Equations 139 (2010), 1-9.

[8] L. GUO, J. SUN, Y. ZHAO, Existence of positive solutions for nonlinear third-order three-point boundary value problems, Nonlinear Analysis 68 (10) (2008), 3151-3158.

[9] L. GuO, J. Sun, Y. ZHAO, Multiple positive solutions for nonlinear third-order three-point boundaryvalue problems, Electronic Journal of Differential Equations 112 (2007), 1-7.

[10] S. JUng, Approximate solutions of a linear differential equation of third order, Bulletin of the Malaysian Mathematical Sciences Society 35 (4) (2012), 1063-1073.

[11] Y. LI, Y. GuO, G. LI, Existence of positive solutions for systems of nonlinear third-order differential equations, Communications in Nonlinear Science and Numerical Simulation 14 (2009), 3792-3797.

[12] X. LI, J. Sun, F. KonG, Existence of positive solution for a third-order three-point BVP with signchanging Green's function, Electronic Journal of Qualitative Theory of Differential Equations 30 (2013), 1-11.

[13] X. Lin, Z. ZHAO, Iterative technique for a third-order differential equation with three-point nonlinear boundary value conditions, Electronic Journal of Qualitative Theory of Differential Equations 12 (2016), 1-10.

[14] S. PADHI, On the asymptotic behaviour of solutions of third order delay differential equations, Nonlinear Analysis 34 (3) (1998), 391-403. 
[15] A. P. Palamides, N. M. StaVRakakis, Existence and uniqueness of a positive solution for a thirdorder three-point boundary-value problem, Electronic Journal of Differential Equations 155 (2010), 1971-1975.

[16] M. PEI, S. ChANG, Existence and uniqueness of solutions for third-order nonlinear boundray value problems, Journal of Mathematical Analysis and Applications 327 (2007), 23-35.

[17] J. Sun, Q. REN, Y. ZHAO, The upper and lower solution method for nonlinear third-order threepoint boundary value problem, Electronic Journal of Qualitative Theory of Differential Equations 26 (2010), 1-8.

[18] Y. SUN, Positive solutions of singular third-order three-point boundary value problems, Journal of Mathematical Analysis and Applications 306 (2005), 589-603.

[19] Y. SUn, Positive solutions for third-order three-point nonhomogeneous boundary value problems, Applied Mathematics Letters 22 (2009), 45-51.

[20] F. J. TORRES, Positive solutions for a third-order three-point boundary-value problem, Electronic Journal of Differential Equations 147 (2013), 1-11.

[21] C. WANG, R. Hong, Positive solutions for a class of singular third-order three-point nonhomogeneous boundary value problem, Dynamic Systems and Applications 19 (2) (2010), 225-234.

[22] F. WANG, Y. CUI, On the existence of solutions for singular boundary value problem of third-order differential equations, Mathematica Slovaca 60 (4) (2010), 485-494.

[23] W. XIE, H. PANG, The shooting method and integral boundary value problems of third-order differential equation, Advances in Difference Equations 138 (2016), 2016.

[24] Q. YAO, Y. FENG, Existence of solution for a third-order two-point boundray value problem, Applied Mathematics Letters 15 (2002), 227-232.

[25] Q. YAO, Positive solutions of singular third-order three-point boundary value problems, Journal of Mathematical Analysis and Applications 354 (2009), 207-212.

[26] C. Zhai, L. ZhaO, S. Li AND H. R. MARASI, On some properties of positive solutions for a thirdorder three-point boundary value problem with a parameter, Advances in Difference Equations $\mathbf{1 8 7}$ (2017), 2017.

[27] C. Zhai, C. YAng, X. Zhang, Positive solutions for nonlinear operator equations and several classes of applications, Mathematische Zeitschrift 266 (2010), 43-63.

[28] X. Zhang, L. LiU, Nontrivial solution of third-order nonlinear eigenvalue problems (II), Applied Mathematics and Computation 204 (2008), 508-512.

[29] C. ZHAO, Q. ZHOU, On the asymptotic behavior of solutions for a third-order nonlinear differential equation, Vietnam Journal of Mathematics 39 (1) (2011), 71-77. 